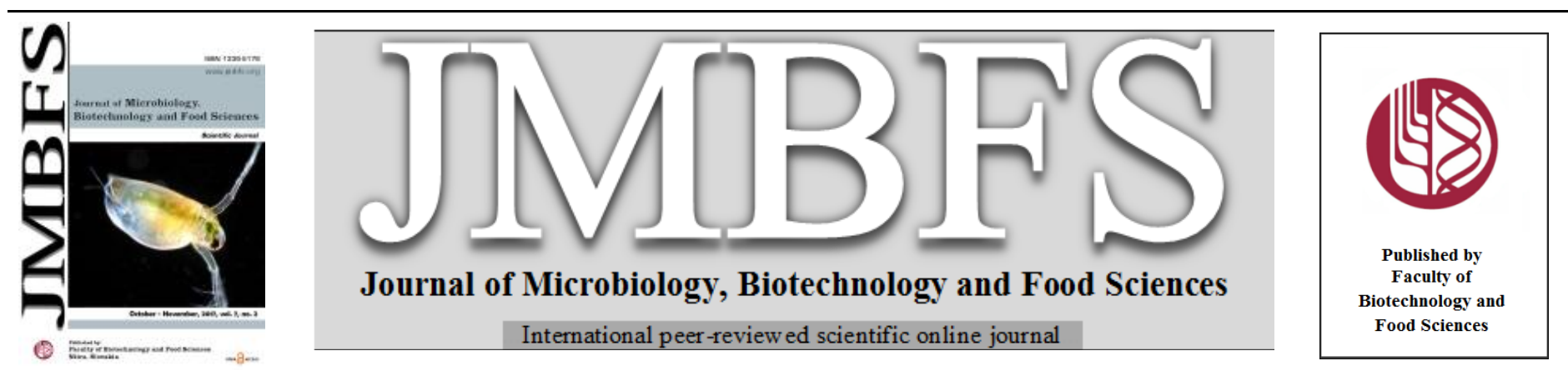

\title{
FUNGAL DIVERSITY ASSOCIATED WITH PEARL MILLET PENNISETUM GLAUCUM L.) GRAINS FROM TAIZ GOVERNORATE, YEMEN AND THEIR AMYLASE PRODUCTION
}

\author{
Sobhy Ibrahim Ismail Abdel-Hafez ${ }^{1}$, Mohamed Ahmad Abdel-Sater ${ }^{1}$, Nemmat Abdel-Gawad Hussein ${ }^{* 1}$ and Eshraq Abdul-WahapAL- \\ Amery $^{2}$
}

\begin{abstract}
Address(es):
${ }^{1}$ Assiut University, Faculty of Science, Botany and Microbiology Department, Postal code: 71516, Assiut, Egypt.

${ }^{2}$ Taiz University, Faculty of Applied Science, Microbiology Department, Taiz, Yemen.
\end{abstract}

*Corresponding author: nemmgoda@yahoo.com

doi: $10.15414 / j m b f s .2017 .7 .2 .118-123$

\section{ARTICLE INFO}

Received 25. 10. 2016

Revised 4. 5. 2017

Accepted 13. 8. 2017

Published 1. 10. 2017

Regular article

OPEN $\partial_{\text {ACCESS }}$

\begin{abstract}
In Yemen, this is the first record on fungal diversity associated with millet grains. Grain- borne fungi were tested for NaOCl- treated and non- treated samples of millet grain collected from Taiz Governorate, Yemen using direct plate method on Czapek's (Cz) and Czapek's supplemented with $40 \%$ sucrose (Cz40S) agar media. A total of 48 species belonging to 20 genera were isolated. The highest count and number of genera and species were recorded in non- treated grains on Cz40S medium. This means that the majority of fungi associated with grains were osmotolerant/osmophilic. The highest frequencies were represented by Aspergillus flavus, A. niger aggregate, A. vadensis, Eurotium amstelodami, Pencillium duclauxii and Rhizopus stolonifer. Among 109 isolates screened for their ability to produce amylase enzyme, $81.65 \%$ could produce the enzyme, of which Aspergillus homomorphus (a new record in Egypt), Emericella nidulans, Fusarium oxysporum and Penicillium griseofulvum were the best producers. Hence, these fungi may cause degradation of cell walls and spoilage of grains. Moreover, it is important to determine which organisms might be associated with seeds and grains in storage causing quality loss through their growth and enzyme production. The early detection of these organisms is required to prevent their harmful effects.
\end{abstract}

Keywords: Millet, fungal diversity, amylase, Czapek's agar, Czapek's 40\% sucrose, treated and untreated grains

\section{INTRODUCTION}

Millets are a group of highly variable small-seeded grasses, broadly grown as cereal crops for fodder and human food. Pearl millet (Pennisetum glaucum L.) is an important food and forage crop, mainly cultivated in Yemen, Nigeria, Ghana, Cameroon, Sudan, India, Pakistan and other countries in Asia and South Africa About $50-60 \%$ of the cultivated area in Yemen is represented by sorghum and millet (Reddy et al., 2004). According to the data of United States Department of Agriculture, about 80 thousand million tons of pearl millet were annually produced. Millet is rich in starch, nutrients, vitamins, minerals, fats and organic compounds that can significantly boost human health in various ways. It is gluten- free, so Celiac sufferers can turn to millet as their source of grains, instead of wheat. Millet provides energy, has a higher protein content and better amino acid balance than sorghum (Nkama and Ikwelle, 1998).

Storage fungi are involved in deterioration of seeds and grains especially at high moisture contents. Somewhat, more than 50 fungal species have been isolated from seeds and grains, principally Aspergillus, Penicillium, Eurotium spp, with increasing moisture content above $15 \%$, of which, Aspergillus candidus, A. ochraceus, A. flavus, A. versicolor and A. tamarii were the most encountered species (Christensen, 1957). Grain mold is a fungal disease can reduce grain germination or seedling emergence and consequently, reduce the quality of the grain, but, planting early will minimize yield and grain quality losses because it allows the crop to mature before disease developing. Fusarium chlamydosporum, F. semitectum, F. moniliforme, F. solani, Alternaria spp., Aspergillus flavus, Cladosporium herbarum, Curvularia lunata, $C$. pallescens, Drechslera longirostrata, D. spicifer, D. terramera, Mortierella exigua, Mucor spp., Penicillium oxalicum, Penicillium spp., Pythium sp., Stachybotrys chartarum, Torula herbarum, Syncephalastrum racemosum, and Rhizopus spp. were isolated previously from millet and sorghum in Egypt or from millet in USA, India and Eritrea (Moubasher, 1993; Naqvi et al., 2013; Khairnar, 2014; Zohri et al., 2014; Mousa et al., 2015).

Microbial amylases have immense applications on various fields in world market because of their wide applications in industries including food, brewing, distilling industry, textile, paper, pharmaceutical and bioconversion of solid wastes (Lall $\boldsymbol{e t}$ al., 2015). Several filamentous fungi have proven to be an important source of industrial enzymes, due to their diversity (Ogbonna et al., 2015). Many species of Aspergillus (A. flavus, A. fumigatus, A. niger aggregate, A. ochraceus, A. oryzae and A. terreus), Emericella nidulans, Mucor racemosus, Mycosphaerella tassiana, Penicillium chrysogenum, Rhizopus oligosporus and $R$. stolonifer are used as sources of fungal $\alpha$ - amylases (Irfan et al., 2012; Singh et al., 2014).

The objective of the current study was designed to assess the fungal diversity of millet grains collected from Taiz Governorate, Yemen. Also, amylase production by isolated fungi was evaluated.

\section{MATERIAL AND METHODS}

Collection of samples

Twenty samples of millet grains were collected from different markets, (local stores), in Taiz Governorate, Yemen. The samples were put in clean polyethylene plastic bags and brought to the Mycological Laboratory and keep at $5^{\circ} \mathrm{C}$ till fungal analysis.

Determination of moisture content (MC\%)

The moisture content was estimated using the method described by Abdel-Hafez et al., (2014) and expressed as percentage of the dry-weight.

\section{Germinability (Grain germination) test}

Ten millet grains from each sample were first surface- sterilized by shaking in $2 \%$ sodium hypochloride solution for 5 minutes, rinsed three times by sterilized distilled water. Thereafter it was incubated at $25^{\circ} \mathrm{C}$ over a pad of moist sterile filter paper, then, placed in a sterile Petri dish for 7-10 days. The grain with healthy roots and plumules was counted and expressed as percentage according to the formula recommended by Gummert (2011). Germination percentage (GP) $=$ Number of germinated seeds/total number of seeds $\mathrm{x} 100$. 


\section{Isolation and identification of fungi}

The direct- plating technique was used to determine grain- borne fungi of millet Czapek's (Cz) and Czapek's supplemented with 40\% sucrose (Cz40S) agar media were used for isolation and identification of fungi. Two methods were used for isolation, grains were either placed directly on the surface of agar plate (non- treated) or surface- sterilized by $1 \%$ sodium-hypochlorite $(\mathrm{NaOCl})$ (treated) (Pitt et al., 1992). Five grains from each sample were put on the surface of agar plate and four replicates were used. All plates were incubated at $28^{\circ} \mathrm{C}$ for 7 days and the developing fungi were counted, isolated, identified and calculated as colony forming units (CFUs) per 20 grains for each sample. Pure cultures were cultivated on appropriate media (Czapek's agar, Czapek yeast autolysate agar and potato dextrose agar) and incubated at $28^{\circ} \mathrm{C}$ for identification. Microscopic examination of preparations of the different fungal species stained with lactophenol cotton blue was carried out. To distinguish $A$. candidus from other members of Section Candidi especially A. tritici, the isolates were grown for 7 days as 3-point inoculations on Czapek yeast autolysate agar (CYA) at $37^{\circ} \mathrm{C}$ Aspergillus species were identified phenotypically using the standard media (e.g Czapek agar, CYA and MEA at 25C and on CYA at 37C) as recommended by Raper and Fennell (1965), Samson and Varga (2007) and Pitt and Hocking (2009), whereas, Penicillium species using the standard methodology (3 media and 3 incubation temperatures) recommended by Pitt (1979) and Pitt and Hocking (2009), Fusarium species using standard media and temperatures and following the keys and descriptions of Leslie and Summerell (2006) and Ismail et $a l .$, (2015) and for other genera following the descriptive and dichotomous keys of Ellis (1971); Domsch et al., (2007); Moubasher (1993); Pitt and Hocking (2009). Moreover, a doubtful isolate related to Section Nigri was identified molecularly by DNA sequencing using ITS1 ((5' - TCC GTA GGT GAA CCT GCG G - 3') and ITS4 (5'- TCC TCC GCT TAT TGA TAT GC -3') primers in SolGent company (Daejeon, Stouth Korea). The sequence obtained from the isolate was further analyzed using BLAST from the National Center of Biotechnology Information (NCBI) website and identified as Aspergillus homomorphus.

\section{Screening for $\alpha$ - amylase production}

One hundred and nine isolates of 44 fungal species related to 20 genera collected from millet grains were assayed for their ability to produce $\alpha$ - amylase enzyme according to the method of Bridge (1985). Fungal isolates were cultured on modified Czapek's agar medium (starch, $30 \mathrm{~g} ; \mathrm{NaNO}_{3}, 3 \mathrm{~g} ; \mathrm{KH}_{2} \mathrm{PO}_{4}, 1.0 \mathrm{~g}$; $\mathrm{MgSO}_{4} .7 \mathrm{H}_{2} \mathrm{O}, 0.5 \mathrm{~g} ; \mathrm{KCL}, 0.5 \mathrm{~g} ; \mathrm{FeSO}_{4}, 0.01 \mathrm{~g}$; agar, $15 \mathrm{~g}$ and distilled water, $1000 \mathrm{ml})$. The medium was inoculated with fungal isolates and incubated at $28^{\circ} \mathrm{C}$, then flooded with iodine solution (iodine, $0.2 \mathrm{ml}$; potassium iodide, $0.4 \mathrm{ml}$ and distilled water, $100 \mathrm{ml}$ ). A clear zone around fungal growth indicated the production of amylase (Cowan 1974). Enzyme index (EI) was calculated according to Ho and Foster (1972) as follows:

Enzyme index $(\mathrm{EI})=\frac{\text { Diameter of the outer limited of the clear zone }}{\text { Diameter of the fungat }}$

$$
\text { Diameter of the fungal colony }
$$

\section{RESULTS AND DISCUSSION}

\section{Moisture contents (MC\%)}

The moisture contents (MC\%) of all millet grain samples ranged from $9.4-$ 12.9\%. Sample numbers 16 (from ALaamor village, Taiz, Yemen), 18 and 20 (from 26 September street, Taiz, Yemen) followed by no 19 (from 26 September street) and 17 (from ALaamor village) recorded the highest MC\%, on contrast, samples numbers 1 and 2 (from Alshenany, , Taiz, Yemen) were the lowest in their moisture contents (Table 1).

When the moisture contents of seeds and grains are raised artificially, the seedand grain-borne fungi grow competitively to colonize and invade the seed Several fungi could significantly increase their numbers at the different levels of moisture content. The degree of dominance among fungi differed according to the moisture level (Moubasher et al., 1980). Abdel-Hafez et al., (2014) noticed that the moisture contents of cereal grains (maize and sorghum) ranged between $8.75-16.76 \%$ in maize and $7.16-13.63 \%$ in sorghum.

\section{Germination capacity of millet grains}

The results in Table (1) revealed that the percentage germination of 20 grain samples ranging between $50-100 \%$ of the tested grains.

In general, in most samples there is a reverse correlation between moisture content and germination ability of the grain; for example, samples Nos. 1, 3, 4, 5 with relatively low MC\% (9.4-10.4\%) showed the highest G\% (90-100\%). On contrast, samples Nos. 16, 18, 19, 20 with relatively high MC\% (12.7-12.9\%) showed the lowest G\% (50-70\%), whereas, high moisture content enhance fungal growth on the grains. These results are in agreement with the finding of Moubasher et al. (1980). They stated that under low moisture content, fungi cannot grow and invade peanut seeds with slight loss in germinability and the seeds fell off with increasing moisture content. Also, at high levels of relative humidity ( $92-100 \% \mathrm{RH})$, the loss of germination capacity is serious and leads to complete mortality due to increasing in moisture contents of grains (Mazen et al., 1993).

\section{Fungi recovered in the present investigation}

A total of 48 species and one species variety belonging to 20 fungal genera were isolated and identified from both $\mathrm{NaOCl}$ - treated and non- treated millet grains on Czapek's (Cz) and Czapek's supplemented with $40 \%$ sucrose (Cz40S) agar at $28^{\circ} \mathrm{C}$. There is a remarkably high incidence of diverse fungal contamination of the analyzed samples. The genera of highest occurrence and their respective number of species were Aspergillus (15 spp.) and Eurotium (5 spp.). The total viable counts of fungi in all samples were 67 and $103 \mathrm{CFUs} / 400$ of treated grains on $\mathrm{Cz}$ and Cz40S respectively and 384 and $449 \mathrm{CFUs} / 400$ of untreated grains on $\mathrm{Cz}$ and $\mathrm{Cz} 40 \mathrm{~S}$ respectively (Tables 2,3) (Figure 1). Figure (1) showed that the highest total fungal count was recorded in non- treated grains on $\mathrm{Cz} 40 \mathrm{~S}$ medium (449), followed by that isolated on $\mathrm{Cz}$ ( $384 \mathrm{CFUs}$ per 400 grains). Also the highest number of genera and species were detected in non- treated grains on Cz40S (33 species and 15 genera) (Figure 2). Isolates of A. candidus showed no growth on CYA at $37^{\circ} \mathrm{C}$ and this differentiate it from A. tritici (Varga et al. 2007).

Table 1 Localities, moisture content (MC\%) and germinability (G\%) of 20 millet grain samples tested.

\begin{tabular}{|c|c|c|c|}
\hline Sample No & Locality & $\mathrm{MC} \%$ & $\mathrm{G} \%$ \\
\hline 1 & Alshenany & 9.4 & 90 \\
\hline 2 & Alshenany & 9.6 & 60 \\
\hline 3 & Alshenany & 10.4 & 100 \\
\hline 4 & Alshenany & 10.4 & 100 \\
\hline 5 & Alshenany & 10.4 & 100 \\
\hline 6 & Alsamsara & 11.6 & 70 \\
\hline 7 & Alsamsara & 11.6 & 90 \\
\hline 8 & Alsamsara & 11.5 & 90 \\
\hline 9 & Alsamsara & 11.7 & 90 \\
\hline 10 & Alsamsara & 11.4 & 100 \\
\hline 11 & Alsamsara & 11.2 & 70 \\
\hline 12 & Bearbasha & 11.3 & 90 \\
\hline 13 & Bearbasha & 11.3 & 80 \\
\hline 14 & Bearbasha & 11.1 & 80 \\
\hline 15 & ALaamor village & 11.4 & 80 \\
\hline 16 & ALaamor village & 12.9 & 60 \\
\hline 17 & ALaamor village & 12.6 & 90 \\
\hline 18 & 26 September Street & 12.9 & 50 \\
\hline 19 & 26 September Street & 12.7 & 70 \\
\hline 20 & 26 September Street & 12.9 & 70 \\
\hline
\end{tabular}

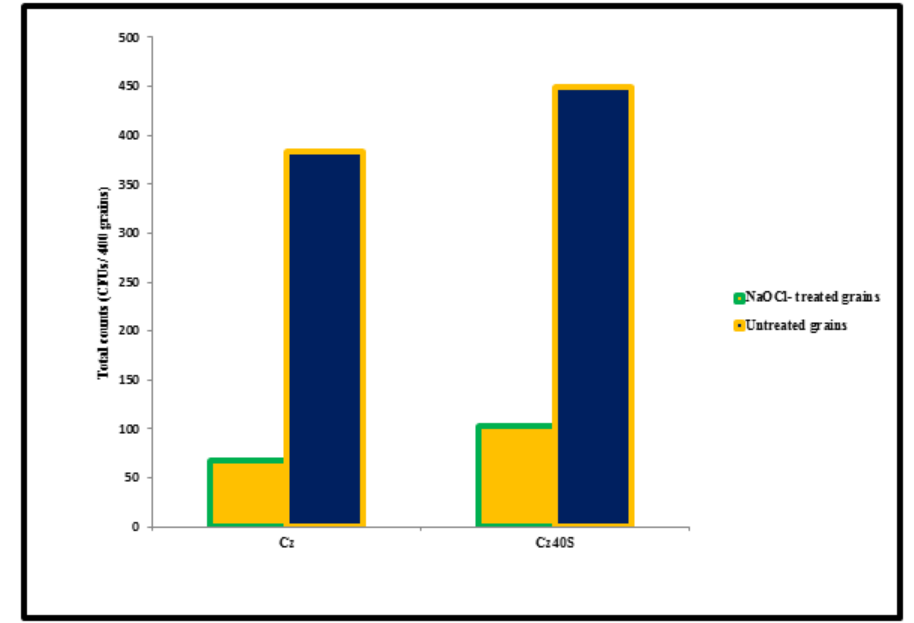

Figure 1 Total counts of fungi isolated from $\mathrm{NaOCl}$ - treated and untreated millet grains (per 400 grains) on $\mathrm{Cz}$ and $\mathrm{Cz} 40 \mathrm{~S}$ agar media 


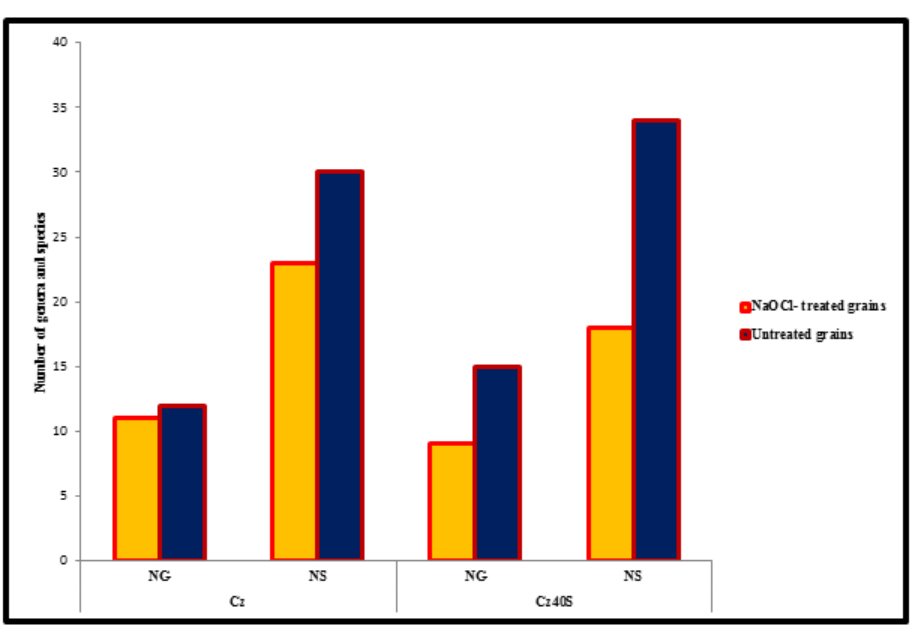

Figure 2 Number of genera (NG) and species (NS) of fungi isolated from $\mathrm{NaOCl}$ - treated and untreated millet grains (per 400 grains) on $\mathrm{Cz}$ and $\mathrm{Cz} 40 \mathrm{~S}$ agar media

\section{Fungi isolated from NaOCl- treated grains}

Twenty-two identified species +1 species variety and 18 species appertaining to 11 and 9 genera were collected from $\mathrm{NaOCl}$ - treated millet grains on $\mathrm{Cz}$ and $\mathrm{Cz} 40 \mathrm{~S}$ at $28^{\circ} \mathrm{C}$ respectively (Table 2 ).

On $\mathrm{Cz}$ agar medium, Aspergillus ( 5 species +1 variety) was consistently the most frequent genus (50\% of total samples) and had the highest percentage total counts (28.36\% of total fungi). From the genus, A. flavus (20\% of total samples and $10.45 \%$ of total fungi) and $A$. vadensis $(20 \%, 5.97 \%)$ were the most common species. The remaining species were isolated in rarely from $5-10 \%$ of total samples, matching collectively about $12 \%$ of total fungi. The runner- up is black sterile mycelia which represented $40 \%$ of total samples and $22.38 \%$ of total fungi, followed by Drechslera halodes (30\% and 13.4\%) and Curvularia (2 species, $25 \%, 11.94 \%)$. The remaining genera and their respective species were isolated in rare frequency (Table 2).

On Cz40S agar medium, Eurotium (4 spp.) and Aspergillus (5 spp.) recorded the highest frequencies ( $60 \%$ and $45 \%$ of total samples respectively), comprising
$33.98 \%$ and $23.3 \%$ of total fungi respectively. Moderate and low frequencies were represented by black sterile mycelia (35\% of total samples and $19.4 \%$ of total fungi), Cladosporium (25\% and 5.83\%) and Curvularia (15\% and $8.74 \%$ ). The most prevalent species were Aspergillus flavus (35\%), Eurotium amstelodami (30\%), E. rubrum (25\%), E. repens, A. niger and Cladosporium cladosporioides (20\% each) (Table 2).

This is the first report on the occurrence and diversity of fungi in millet grains cultivated in Yemen, but there are some other studies from different countries Overall, mold load was significantly higher in 16 samples tested of fonio millet (range $=2.30-4.88$, mean $=4.12 \pm 0.64 \log 10 \mathrm{CFU} / \mathrm{g}$ ) than in 17 samples tested of sesame (range $=2.48-3.98$, mean $=2.97 \pm 1.09 \log 10 \mathrm{CFU} / \mathrm{g}$ ) in Plateau State, Nigeria (Ezekiel et al., 2014). Khairnar (2014) isolated 23 fungal species belong to 12 genera from seeds of eight different cultivars by treated and untreated seeds from pearl millet in Maharashtra, India.

A great number of fungi that recorded in the present investigation from pearl millet grains were previously isolated from different localities of the world. According to Agrios (1978), the most common storage fungi are Aspergillus and Penicilium species. Seed infestation by microorganisms is a common and widespread phenomenon which has been variously reported. Amadi and Adeniyi (2009) isolated A. terreus, A. flavus, A. niger, P. italicum, P. spinulosum, $R$. stolonifer and Fusarium species from stored rice, maize and millet grains surface sterilized in $\mathrm{NaOCl}$ from Niger State, Nigeria, but A. terreus, A. flavus were detected only in finger millet grains. Various fungi (Alternaria alternata, Aspergillus candidus, A. flavus, A. fumigatus, A. niger, A. sydowii, A. tamarii, A. versicolor, $C$. cladosporioides, $C$. herbarum, E. amstelodami, F. moniliforme, $F$ oxysporum and others) were recorded on Czapek's agar from paddy grains collected from different Governorates in Egypt (Mazen et al., 1993). Abe et al., (2015) recorded Fusarium verticillioides as the most frequently species on maize grains and Aspergillus flavus was the second most diverse, but Cladosporium cladosporioides, Epicoccum nigrum and Mucor sp. were rarely isolated. A total of 158 fungal isolates were cultured and identified from 83 surface sterilized mouldy millet grain samples studied in the state. Ten genera of fungi namely Aspergillus (70 isolates), Penicillium (43), Fusarium (23), Rhizopus (6), Mucor (5), Syncephalastrum (4), Phoma (4), Cladosporium (1), Arthroconidia (1) and Helminthosporium (1) were the identified fungal contaminants of surface sterilized millet grains in the Niger State, Nigeria (Makun et al., 2007).

Table 2 Total counts (TC, calculated per 400 grains in all samples), percentage total counts (TC\%) and percentage frequency (F\%, calculated per 20 samples) of fungi isolated from NaOCl- treated millet grain samples on Czapek's and Czapek's supplemented with $40 \%$ sucrose agar media at $28^{\circ} \mathrm{C}$

\begin{tabular}{|c|c|c|c|c|c|c|}
\hline \multirow{2}{*}{ Fungal Taxa } & \multicolumn{3}{|c|}{ Czapek's agar } & \multicolumn{3}{|c|}{ Czapek's $40 \%$ sucrose agar } \\
\hline & TC & TC\% & F\% & TC & TC\% & F\% \\
\hline Acremonium W. Gams & 2 & 2.99 & 10 & & & \\
\hline A. blochii (Matruchot) W.Gams & 1 & 1.5 & 5 & & & \\
\hline A. strictum W. Gams & 1 & 1.5 & 5 & & & \\
\hline Alternaria Nees: Fries & 2 & 2.99 & 5 & 1 & 0.97 & 5 \\
\hline A. alternata (Fr.) Keissler & 1 & 1.5 & 5 & & & \\
\hline A. chlamydospora Mouchacca & 1 & 1.5 & 5 & & & \\
\hline A. citri Ellis and Pierce emend. Bliss \& Fawcett & & & & 1 & 0.97 & 5 \\
\hline Aspergillus P. Micheli ex Link & 19 & 28.36 & $\mathbf{5 0}$ & 24 & 23.3 & 45 \\
\hline A. flavus Link & 7 & $\mathbf{1 0 . 4 5}$ & 20 & 11 & 10.7 & 35 \\
\hline A. flavus var. columnaris Raper \& Fennell & 3 & 4.5 & 10 & & & \\
\hline $\begin{array}{l}\text { A. homomorphus Steiman, Guiraud, Sage \& Seigle- } \\
\text { Mur. }\end{array}$ & 1 & 1.5 & 5 & & & \\
\hline A. niger aggregate & 3 & 4.5 & $\mathbf{1 0}$ & 5 & 4.8 & $\mathbf{2 0}$ \\
\hline A. ochraceus Wilhelm & & & & 2 & 1.94 & $\mathbf{1 0}$ \\
\hline A. sydowii (Bain. \& Sart.) Thom \& Church & 1 & 1.5 & 5 & & & \\
\hline A. terreus Thom & & & & 1 & 0.97 & 5 \\
\hline A. vadensis Samson,de Vries, Frisvad \& Visser & 4 & 5.97 & 20 & 5 & 4.8 & 10 \\
\hline Cladosporium Link & 2 & 2.99 & $\mathbf{1 0}$ & 6 & 5.83 & 25 \\
\hline C. cladosporioides (Fresenius) de Vries & 1 & 1.5 & 5 & 5 & 4.8 & 20 \\
\hline C. herbarum (Persoon) Link & 1 & 1.5 & 5 & 1 & 0.97 & 5 \\
\hline Cochliobolus spicifer Nelson & 1 & 1.5 & 5 & & & \\
\hline Curvularia Boedijn & 8 & 11.94 & 25 & 9 & 8.74 & 15 \\
\hline C. lunata (Wakker) Boedijn & 4 & 5.97 & 15 & 4 & 3.9 & 10 \\
\hline C. ovoidea (Hiroe and Watan.) Muntanole & 4 & 5.97 & 20 & 5 & 4.8 & 5 \\
\hline Drechslera halodes (Drechsler) Subram. and Jain & 9 & 13.4 & 30 & 1 & 0.97 & 5 \\
\hline Emericella Berkeley and Broome & 2 & 2.99 & 10 & & & \\
\hline E. nidul ans (Eidam) Vuillemin & 1 & 1.5 & 5 & & & \\
\hline E. rugulosa (Thom \& Raper) Benjamin & 1 & 1.5 & 5 & & & \\
\hline Eurotium Mangin & 4 & 5.97 & 15 & 35 & 33.98 & $\mathbf{6 0}$ \\
\hline
\end{tabular}


Table 2 Continued.

\begin{tabular}{|c|c|c|c|c|c|c|}
\hline \multirow[b]{2}{*}{ Fungal Taxa } & \multicolumn{3}{|c|}{ Czapek's agar } & \multicolumn{3}{|c|}{ Czapek's $40 \%$ sucrose agar } \\
\hline & $\mathrm{TC}$ & TC\% & $\mathrm{F} \%$ & $\mathrm{TC}$ & $\mathrm{TC} \%$ & $\mathrm{~F} \%$ \\
\hline E. amstelodami Mangin & & & & 15 & 14.6 & 30 \\
\hline E. intermedium Blaser & & & & 1 & 0.97 & 5 \\
\hline E.pseudoglaucus Blochwitz & 3 & 4.5 & 10 & & & \\
\hline E. repens de Bary & 1 & 1.5 & 5 & 4 & 3.9 & 20 \\
\hline E. rubrum Konig et al. & & & & 15 & 14.6 & 25 \\
\hline Fusarium Link & 2 & 2.99 & 5 & 1 & 0.97 & 5 \\
\hline F. sambucinum Fuckel & 1 & 1.5 & 5 & 1 & 0.97 & 5 \\
\hline F. verticillioides (Sacc.) Nirenberg & 1 & 1.5 & 5 & & & \\
\hline Penicillium griseofulvum Dierckx & & & & 2 & 1.94 & 10 \\
\hline Scytalidium sp. Pesante & & & & 4 & 3.9 & 5 \\
\hline Sterile mycelia (black) & 15 & 22.38 & 40 & 20 & 19.4 & 35 \\
\hline Ulocladium alternariae (Cooke) Simmons & 1 & 1.5 & 5 & & & \\
\hline Total count & & 67 & & & 10. & \\
\hline No. of genera & & 11 & & & 9 & \\
\hline No. of species $\quad(30+1$ variety $)$ & & $22+1$ val & & & 18 & \\
\hline
\end{tabular}

Fungi isolated from untreated grains

Twelve and 15 genera including 29 species +1 variety, and 33 species +1 variety were isolated from 400 untreated millet grains on $\mathrm{Cz}$ and $\mathrm{Cz} 40 \mathrm{~S}$ agar media respectively (Tables 3 )

$\mathrm{On} \mathrm{Cz}$ agar medium, the highest frequencies of fungal genera and their species were represented by Aspergillus (11 spp. +1 var.) and Fusarium (4 spp.), followed by Curvularia (2 spp.), Drechslera (1 sp.), Rhizopus (1 sp.) and black sterile mycelia. They were detected in $95 \%, 45 \%, 35 \%, 35 \%, 35 \%$, and $35 \%$ of the grain samples, comprising $70.3 \%, 4.7 \%, 3.13 \%, 1.82 \%, 3.91 \%$ and $7.03 \%$ of total fungi respectively. The best counts were recorded by Aspergillus (70.3\% of total fungi), followed by sterile mycelia (7.03\%) and Fusarium (4.7\%). The most common species were A. flavus (75\% of the samples), A. niger (60\%), A vadensis (50\%), A. flavus var. columnaris (40\%), Drechslera halodes, Rhizopus stolonifer (35\% each), A. terreus, E. nidulans, Fusarium verticillioides and $M$. circinelloides (30\% each) and Curvularia lunata (25\%) constituting $1.82 \%$ $28.4 \%$ of total fungi (Table 3 )

On Cz40S agar medium, Aspergillus (12 spp. + 1 var.) was recovered from all samples constituting $58.4 \%$ of total fungi. The most prevalent species were $A$ flavus (80\% of total samples, $21.6 \%$ of total fungi), A. niger aggregate $(55 \%$, $9.8 \%)$ and $A$. vadensis $(55 \%, 13.6 \%)$. The second higher incidence rate was Eurotium ( $80 \%$ of the samples and $29.65 \%$ of total fungi) and the commones species was E. amstelodami $(45 \%, 14.7 \%)$. The third common fungi on Cz40S were black sterile mycelia (30\% of total samples and $2.23 \%$ of total fungi), followed by Penicillium (2 spp., 25\% and 1.6\% respectively). From Penicillium, P. duclauxii $(15 \%, 1.11 \%)$ was the most common (Table 3$)$.

Table 3 Total counts (TC, calculated per 400 grains in all samples), percentage total counts (TC\%) and percentage frequency (F\%, calculated per 20 samples) of fungi isolated from non- treated millet grain samples on Czapek's and Czapek's supplemented with $40 \%$ sucrose agar media at $28^{\circ} \mathrm{C}$

\begin{tabular}{|c|c|c|c|c|c|c|}
\hline \multirow{2}{*}{ Fungal Taxa } & \multicolumn{3}{|c|}{ Czapek's agar } & \multicolumn{3}{|c|}{ Czapek's $40 \%$ sucrose agar } \\
\hline & TC & TC\% & $\mathrm{F} \%$ & TC & $\mathrm{TC} \%$ & $\mathrm{~F} \%$ \\
\hline Acremonium blochii (Matruchot) W.Gams & 1 & 0.26 & 5 & & & \\
\hline Alternaria Nees: Fries & & & & 2 & 0.45 & $\mathbf{1 0}$ \\
\hline A. chlamydospora Mouchacca & & & & 1 & 0.22 & 5 \\
\hline A. citri Ellis and Pierce emend. Bliss \& Fawcett & & & & 1 & 0.22 & 5 \\
\hline Aspergillus P. Micheli ex Link & 270 & 70.3 & 95 & 262 & 58.4 & 100 \\
\hline A. brasiliensis Varga, Frisvad \& Samson & 5 & 1.3 & 10 & 6 & 1.34 & 10 \\
\hline A. candidus Link & & & & 2 & 0.45 & 10 \\
\hline A. flavipes (Bain. \& Sart.) Thom and Church & & & & 1 & 0.22 & 5 \\
\hline A. flavus Link & 109 & 28.4 & 75 & 97 & 21.6 & 80 \\
\hline A. flavus var. columnaris Raper \& Fennell & $\mathbf{3 0}$ & 7.8 & 40 & 28 & 6.24 & 35 \\
\hline A. fumigatus Fresenius & 2 & 0.52 & 10 & & & \\
\hline $\begin{array}{l}\text { A. homomorphus Steiman, Guiraud, Sage \& Seigle- } \\
\text { Mur. }\end{array}$ & 2 & 0.52 & 10 & 8 & 1.8 & 15 \\
\hline A. niger aggregate & 36 & 9.4 & 60 & 44 & 9.8 & 55 \\
\hline A. parasiticus Speare & 5 & 1.3 & 10 & 3 & 0.7 & 5 \\
\hline A. sydowii (Bain. \& Sart.) Thom \& Church & 7 & 1.82 & 20 & 7 & 1.6 & 30 \\
\hline A. tamarii Kita & 5 & 1.3 & 20 & 1 & 0.22 & 5 \\
\hline A.terreus Thom & 22 & 5.7 & 30 & 3 & 0.7 & 15 \\
\hline A. vadensis Samson,de Vries, Frisvad \& Visser & 46 & 11.97 & $\mathbf{5 0}$ & 61 & 13.6 & 55 \\
\hline A. versicolor (Vuillemin) Tiraboschi & 1 & 0.26 & 5 & 1 & 0.22 & 5 \\
\hline Botryotrichum sp. Saccardo \& Marchal & & & & 3 & 0.7 & 10 \\
\hline Cladosporium cladosporioides (Fresenius) de Vries & 4 & 1.04 & 20 & 10 & 2.23 & 30 \\
\hline Curvularia Boedijn & 12 & 3.13 & 35 & 2 & 0.45 & 10 \\
\hline C. lunata (Wakker) Boedijn & 10 & 2.6 & 25 & 1 & 0.22 & 5 \\
\hline C. ovoidea (Hiroe and Watan.) Muntanole & 2 & $\mathbf{0 . 5 2}$ & 10 & 1 & 0.22 & 5 \\
\hline Drechslera halodes (Drechsler) Subram and Jain & 7 & 1.82 & 35 & 2 & 0.45 & 10 \\
\hline Emericella Berkeley and Broome & 7 & 1.82 & 30 & 2 & 0.45 & 10 \\
\hline E. nidulans (Eidam) Vuillemin & 6 & 1.6 & 30 & 2 & 0.45 & 10 \\
\hline E. rugulosa (Thom \& Raper) Benjamin & 1 & 0.26 & 5 & & & \\
\hline Epicoccum nigrum Link & & & & 1 & 0.22 & 5 \\
\hline Eurotium Mangin & 5 & 1.3 & 5 & 134 & 29.65 & $\mathbf{8 0}$ \\
\hline E. amstelodami Mangin & 5 & 1.3 & 5 & 66 & 14.7 & 45 \\
\hline E. pseudoglaucum (Blochwitz) Malloch \& Cain & & & & 8 & 1.8 & 5 \\
\hline E. repens de Bary & & & & 28 & 6.24 & 20 \\
\hline
\end{tabular}




\begin{tabular}{|c|c|c|c|c|c|c|}
\hline \multirow{2}{*}{ Fungal Taxa } & \multicolumn{3}{|c|}{ Czapek's agar } & \multicolumn{3}{|c|}{ Czapek's $40 \%$ sucrose agar } \\
\hline & TC & TC\% & $\mathrm{F} \%$ & TC & TC\% & F\% \\
\hline E. rubrum Konig et al. & & & & 32 & 7.13 & 30 \\
\hline Fusarium Link & 18 & 4.7 & 45 & 4 & 0.9 & $\mathbf{1 0}$ \\
\hline F. oxysporum Schlechtendal & 2 & 0.52 & 10 & & & \\
\hline F. solani (Martius) Saccardo & 1 & 0.26 & 5 & & & \\
\hline F. sambucinum Fuckel & 5 & 1.3 & $\mathbf{1 0}$ & $\mathbf{1}$ & 0.22 & 5 \\
\hline F. verticillioides (Sacc.) Nirenberg & 10 & 2.6 & 30 & $\mathbf{3}$ & 0.7 & $\mathbf{1 0}$ \\
\hline Humicola fuscoatra Traaen & & & & 1 & 0.22 & 5 \\
\hline Mucor circinelloides van Tieghem & 11 & 2.84 & 30 & 4 & 0.9 & 10 \\
\hline Penicillium Link & 6 & 1.6 & 20 & 7 & 1.6 & 25 \\
\hline P. duclauxii Delacroix & 1 & 0.26 & 5 & 5 & 1.11 & 15 \\
\hline P. funiculosum Thom & 3 & 0.8 & 15 & & & \\
\hline P. griseofulvum Dierckx & 2 & 0.52 & 5 & 2 & 0.45 & $\mathbf{1 0}$ \\
\hline Rhizopus stolonifer (Ehrenberg) Vuillemin & 15 & 3.91 & 35 & 2 & 0.45 & 5 \\
\hline Scopulariopsis candida (Gueguen) Vuill. & & & & 3 & 0.7 & 5 \\
\hline Sterile mycelia (black) & 27 & $\mathbf{7 . 0 3}$ & 35 & 10 & 2.23 & 30 \\
\hline Syncephalastrum racemosum Cohn ex Schroter & 1 & 0.26 & 5 & & & \\
\hline Total count & & 384 & & & 449 & \\
\hline No. of genera (17) & & 12 & & & 15 & \\
\hline No. of species $(40+1$ variety $)$ & & +1 var & & & $33+1$ var. & \\
\hline
\end{tabular}

It is worthy to mention that Acremonium strictum, Alternaria alternata, Cochliobolus specifer and Ulocladium alternariae were recorded only from treated grains on $\mathrm{Cz}$ agar medium. On the other hand, Aspergillus ochraceus, Eurotium intermedium and Scytalidium sp. were isolated only from treated grains on Cz40S agar medium. Some other species were detected only from non- treated grains on either $\mathrm{Cz}$ (A. fumigatus, F. oxysporum, F. solani, P. funiculosum and Syncephalastrum racemosum), or on Cz40S (A. candidus, A. flavipus, Botryotrichum sp., Epicoccum nigrum, Humicola fuscoatra and Scopulariopsis candida) (Tables 2,3).

Also the highest number of genera and species in grains, were detected in untreated grains on Cz40S (33 species and 15 genera) (Figure 2).This means that the majority of fungi associated with millet grains are either osmotolerant or osmophilic, thus, pearl millet grains have higher carbohydrate content $(67.5 \mathrm{~g} /$ $100 \mathrm{~g})$ than maize $(24.6 \mathrm{~g} / 100 \mathrm{~g})$ and the main sugar of the grain is sucrose (NIN 2003; Nambiar et al., 2011). It is worthy to mention that, stored grains have low water activity and this enables xerophilic fungi to grow in this condition (Atanda et al., 2011). Sixteen fungal species were obtained from maize grains from Colombo (Abe $\boldsymbol{e t}$ al., 2015). Thirteen fungal genera were recorded on maize ( 8 genera) and sorghum (7) grains, lentil (5) and sesame (9) seeds using the seed/grain-plate method (Abdel-Hafez et al., 2014).

Ezekiel et al., (2014) isolated species of Alternaria, Aspergillus (A. flavus and A. tamarii), Fusarium and Penicillium from fonio millet and sesame kernels in Plateau State, Nigeria. In a study on mycobiota associated with maize, sorghum, lentil and sesame seeds, Aspergillus was isolated in high frequency from all samples from all substrates with A. flavus and A. niger were the most frequen (Abdel-Hafez et al., 2014). Penicillium was also isolated from all substrates but more frequent in lentil and sesame seeds. Alternaria was also isolated from all substrates but in low frequency from sorghum and lentil and in rare frequency from maize and sesame. Aspergillus flavus, A. terreus, Emericella nidulans, $F$ usarium oxysporum, F. moniliforme and Penicillium griseofulvum were detected previously from finger millet in Andhra Pradesh of India (Penugonda et al. 2010).

A. homomorphus, the first record in Egypt, was isolated once from treated mille grain on $\mathrm{Cz}$ and also it was recorded herein from untreated grains on both isolation media.

\section{$\alpha-$ Amylase production}

Among the 109 isolates tested, 89 (81.65\% of the total isolates) were able to produce amylase enzyme. A. homomorphus, E. nidulans, $F$. oxysporium and $P$. griseofulvum exhibited the highest amylase production, while $C$. cladosporioides, $C$. herbarum, E. nigrum, $F$. solani, $F$. verticillioides, $P$. duclauxii, $P$. funiculosum and $S$. racemosum were weak producers (Table 4$)$. The negative enzyme producers (20 isolates) were related to Botryotrichum sp. (1), Eurotium amstelodami (5), E. intermedium (3), E. pseudoglaucum (1), E. repens (5) and E. rubrum (5) (Table 4).

Fungal extracellular enzymes may play an important role in biodeterioration of dried seeds and grains of several plants, and in propagation of toxigenic and pathogenic fungal strains. The results indicated that, Eurotium spp. failed to grow on starch medium because they are osmophiles and accordingly they were unable to produce the enzyme. Our results were greatly similar with the findings of Dar et al., (2014) who recorded that Eurotium rubrum had least enzyme activity. Our finding on the lack of amylase production by xerophilic fungus, Eurotium, did not agree with that of Ulfig et al., (2009). It was found that fungi isolated from pearl millet in India A. alternata, A. fumigatus, A. niger, E. nidulans, Cladosporium herbarum, Curvularia lunata, F. oxysporum, P. oxalicum and Rhizopus nigricans have the ability to produce amylase (Khairnar, 2014) and $A$ flavus and Curvularia pallescens were high producers. The above mentioned fungi were previously recorded as $\alpha$ - amylase producers from various substrates (Lall et al., 2015; Dar et al., 2014; Pathak et al., 2014).

Table 4 Screening of fungal isolates recovered from Millet for $\alpha$-amylase production

\begin{tabular}{|c|c|c|c|}
\hline Fungal Taxa & NIT & NPI & EI \\
\hline Acremonium blochii & 1 & 1 & $\mathbf{1 . 0 5}$ \\
\hline A. strictum & 1 & 1 & 1.1 \\
\hline Alternaria chlamydospora & 1 & 1 & $\mathbf{1 . 0 5}$ \\
\hline A. citri & 1 & 1 & 1.1 \\
\hline Aspergillus brasiliensis & 1 & 1 & 1.1 \\
\hline A. flavus & 18 & 18 & $1.02-1.13$ \\
\hline A. flavus var. columnaris & 1 & 1 & $\mathbf{1 . 0 3}$ \\
\hline A. fumigatus & 1 & 1 & 1.1 \\
\hline A. homomorphus & 1 & 1 & 1.4 \\
\hline A. niger aggregate & 7 & 7 & 1.1 \\
\hline A. ochraceus & 1 & 1 & 1.04 \\
\hline A. tamari & 1 & 1 & $\mathbf{1 . 0 3}$ \\
\hline A.terreus & 6 & 6 & $1.04-1.15$ \\
\hline A. vadensis & 2 & 2 & 1.1 \\
\hline A. versicolor & 1 & 1 & $\mathbf{1 . 0 5}$ \\
\hline Botryotrichum sp. & 1 & - & $\mathbf{0}$ \\
\hline Cladosporium cladosporioides & 4 & 4 & 1 \\
\hline C. herbarum & 2 & 2 & 1 \\
\hline Cochliobolus spicifer & 1 & 1 & 1.3 \\
\hline Curvularia lunata & 5 & 5 & $1.04-1.3$ \\
\hline C. ovoidea & 5 & 5 & $1-1.3$ \\
\hline Drechslera halodes & 3 & 3 & $1.2-1.3$ \\
\hline Emericella nidulans & 1 & 1 & 1.4 \\
\hline E. rugulosa & 1 & 1 & 1.3 \\
\hline Epicoccum nigrum & 1 & 1 & 1 \\
\hline Eurotium amstelodami & 5 & - & ng \\
\hline E. intermedium & 3 & - & ng \\
\hline E. Pseudoglaucus & 1 & - & ng \\
\hline E. repens & 5 & - & ng \\
\hline E. rubrum & 5 & - & ng \\
\hline Fusarium oxysporum & 1 & 1 & 1.4 \\
\hline F. solani & 1 & 1 & 1 \\
\hline F. sambucinum & 1 & 1 & 1.1 \\
\hline F. verticillioides & 3 & 3 & 1 \\
\hline Humicola fuscoatra & 1 & 1 & 1.1 \\
\hline Mucor circinelloides & 1 & 1 & $\mathbf{1 . 0 3}$ \\
\hline Pencillium duclauxii & 2 & 2 & 1 \\
\hline P. griseofulvum & 5 & 5 & $1-1.4$ \\
\hline P. funiculosum & 2 & 2 & 1 \\
\hline Rhizopus stolonifer & 1 & 1 & $\mathbf{1 . 0 3}$ \\
\hline Scopulariopsis candida & 1 & 1 & $\mathbf{1 . 0 5}$ \\
\hline Scytalidium sp. & $\mathbf{1}$ & 1 & 1.04 \\
\hline Syncephalastrum racemosum & 1 & 1 & 1 \\
\hline Ulocladium alternariae & 1 & 1 & 1.04 \\
\hline Total number & 109 & 89 & \\
\hline
\end{tabular}

NIT $=$ Number of isolates tested, NPI = Number of positive isolates, EI = Enzyme index and $n g=$ No growth . 


\section{CONCLUSION}

This is the pioneer work on fungal diversity associated with millet, which is the very important crop in Yemen. Aspergillus flavus, A. vadensis and D. halodes were the most common on $\mathrm{Cz}$ medium, whereas, on $\mathrm{Cz} 40 \mathrm{~S}$ A. flavus, Eurotium amstelodami, E. rubrum, E. repens, A. niger aggregate and Cladosporium cladosporioides had the highest frequencies. The highest frequencies of fungi of non- treated grains were A. flavus, A. niger aggregate, A. vadensis, E. amstelodami, $P$. duclauxii and $R$. stolonifer. Most fungi isolated from millet have the ability for amylase production which may cause degradation of plant cell walls and spoilage of grains. It is important to know which organisms might cause spoilage problems and the early detection of these organisms is importance to prevent the spoilage. Also, there is urgent need to further studies on fung associated with millet and other important crops in Yemen and role of their enzyme productions in biodeterioration of stored grains.

\section{REFERENCES}

Abdel-Hafez, S. I. I., Ismail, M. A., Nemmat A. Hussein \& Nevein A. AbdelHameed (2014). Fusarium species and other fungi associated with some seeds and grains in Egypt, with 2 newly recorded Fusarium species. Journal of Biological and Earth Sciences, 4(2), 120-129.

Abe, C. A. L., Faria, C. B., Castro, F. F., Souza, S. R., Santos, F. C., Silva, C. N., Tessmann, D. J. \& Barbosa, I. P. (2015). Fungi isolated from maize (Zea mays L.) grains and production of associated enzyme activities. International Journal of Molecular $\quad$ Sciences, 16(7), 15328-15346. http://dx.doi.org/10.3390/ijms160715328

Agrios, N. G. (1978). Plant pathology. Academic Press, New York, pp.703.

Amadi, J.E. \& Adeniyi, D.O. (2009). Mycotoxin production by fungi isolated from stored grains. African Journal of Biotechnology, 8(7), 1219-1221.

Atanda, S. A., Pessu, P. O., Agoda, S., Isong, I. U., Adekalu, O. A., Echendu, M. A. \& Falade T.C. (2011). Fungi and mycotoxins in stored foods. African journal of microbiology research, 5(25), 4373-4382. http://dx.doi.org/10.5897/AJMR11.487

Bridge, P. D. (1985). An evaluation of some physiological and biochemical methods as an aid to the characterization of species of Penicillium subsection fasciculata. Journal of general microbiology, 131, 1887-1895.

Christensen, C. M. (1957). Deterioration of stored grains by fungi. Miscellaneous Journal Series, Minnesota Agricultural Experiment Station, 23(2), 108-134.

Cowan, S. T. (1974). Cowan and Steel's Manual for the Identification of medical bacteria, $2^{\text {nd }}$ edn. Cambridge University Press, Cambridge, pp. 250.

Dar, G. H., Kamil, A. N., Nazir, R., Bandh, S. A. \& Malik, T. A. (2014). Biotechnology production of $\alpha$ - amylase for industrial purpose: Do fungi have potential to produce $\alpha$ - amylase?. International Journal of Biotechnology and Molecular Biology Research, 5(4), 35- 40. http://dx.doi.org/10.5897/IJBMBR

Domsch, K. H., Gams, W. \& Anderson, T. H. (2007). Compendium of Soil Fungi. $2^{\text {nd }}$ edition, IHC-Verlag, Eching, $672 \mathrm{pp}$.

Ellis, M. B. (1971). Dematiaceous Hyphomycetes. Commonwealth Mycological Institute, Kew, Surrey, England, 608 pp.

Ezekiel, C. N., Udom, I. E., Frisvad, J. C., Adetunji, M. C., Houbraken, J., Fapohunda, S. O., Samson, R. A., Atanda, O. O., Agi-Otto, M. C. \& Onashile, O.A. (2014). Assessment of aflatoxigenic Aspergillus and other fungi in millet and sesame from Plateau State, Nigeria. Mycology, 5(1), 16-22. http://dx.doi.org/10.1080/21501203.2014.889769

Gummert, M. (2011). Measuring seed germination. In: Postharvest Fact Sheets. International Rice Research Institute (IRRI), Manila.

Ho, H. H. \& Foster B. (1972). Starch utilization by Phytophthora species. Mycopathologia et Mycologia Applicata, 46(4), 335-339.

Irfan, M., Nadeem M. \& Syed, Q. (2012). Media optimization for amylase production in solid state fermentation of wheat bran by fungal strains. Journal of Cell and Molecular Biology, 10(1), 55-64.

Ismail, M. A., Abdel- Hafez, S. I. I., Nemmat A. Hussein \& Nevein A. AbdelHameed (2015). Contributions to the genus Fusarium in Egypt with dichotomous keys for identification of species. ul. Szkółkarska 88B, 62-002 Suchy Las, Poland, $175 \mathrm{pp}$.

Khairnar, D. N. (2014). Studies on diversity, amylase production by seed- borne fungi of pearl millet and their control measures. International Research Journal of Science and Engineering, 2(2), 68-70.

Lall, B. M., Paul, J. S. \& Jadhav, S. K. (2015). Effect of incubation period (with static and shaking conditions) on $\alpha$ - amylase production from Aspergillus flavus. Advances in Biological Research, 9(1), 1-6. http://dx.doi:10.5829/idosi.abr.2015.9.1.91172

Leslie, J. F. \& Summerrell, B. A. (2006). The Fusarium: Laboratory manual Blackwell Publishing, pp.388. http://dx.doi.org/10.1002/9780470278376

Makun, H. A., Gbodi, T. A., Tijani A. S., Abai, A. \& Kadiri, G.U. (2007). Toxicologic screening of fungi isolated from millet (pennisetum spp.) during the rainy and dry harmattan seasons in Niger state, Nigeria. African Journal of Biotechnology, 6(1), 34-40. http://dx.doi.org/10.5897/AJB

Mazen, M. B., Abdel-Hafez, S. I., El-Kady, I. A. \& El-Maghraby, O. M. (1993). Effect of level of relative humidity on fungi and germination capacity of paddy
(Oryza sativa L.) grains in Egypt. Qatar University Science Journal, 13(1), 81 84.

Moubasher, A. H. (1993). Soil fungi of Qatar and other Arab Countries. The Scientific and Applied Research Centre, University of Qatar, Doha, Qatar, 566 pp.

Moubasher, A. H., Abdel-Hafez, S. I. I., El-Hissy, F. T. \& Hassan, S. K. M (1980). Effect of temperature and moisture content on egyptian peanut seedborne fungi. Mycopathologia, 70(1), 49-54. http://dx.doi:10.1007/BF00704322 Mousa, W. K., Schwan, A., Davidson, J., Strange, P., Liu, H., Zhou, T., Auzanneau, F. I. \& Raizada, M.N. (2015). An endophytic fungus isolated from finger millet (Eleusine coracana) produces anti-fungal natural products Frontiers in Microbiology, 6, 1157. http://dx.doi.org/10.3389/fmicb.2015.01157

N. I. N. 2003. National Institute of Nutrition. Nutritive value of indian foods, Ed Gopalan and Deosthale, Hyderabad.

Nambiar, V. S., Dhaduk, J. J., Sareen, N., Shahu, T. \& Desai, R. (2011). Potential functional implications of pearl millet (Pennisetum glaucum) in health and disease. Journal of Applied Pharmaceutical Science, 1(10), 62- 67.

Naqvi, S. D. Y., Shiden, T., Merhawi, W. \& Mehret, S. (2013). Identification of seed borne fungi on farmer saved sorghum (Sorghum bicolor L.), pearl millet (Pennisetum glaucum L.) and groundnut (Arachis hypogaea L.) seeds. Agricultural Science Research Journals, 3(4), 107-114

Nkama, I. \& Ikwelle, M. C. (1998). Assessment of food quality of millet grain In: pearl millet in Nigeria agriculture production utilization and research priorities. Proceeding of the preseason nationally coordinated research programme of pearl millet. Lake Chad Research Institute Maiduguri, Borno State, Nigeria, 171-178pp

Ogbonna, A. I., Onyimba, I. A., Chuku, A., Nwadiaro, P. O., Ogbonna, C. I. C. \& Onwuliri F. C. (2015). Growth response and amylolytic activity of two Aspergillus species isolated from Artemisia annua L. plantation soils. European Journal of Biotechnology and Biosciencem 3(10), 10-16.

Pathak, S. S., Kumar, S., Rajak, R. C. \& Sandhu, S. S. (2014). Study of effect of temperature on amylase production by soil mycotic flora of jabalpur region. World journal of pharmaceutical sciences, 3(9), 1448-1458.

Penugonda, S., Girisham, S. \& Reddy, S. M. (2011). Elaboration of mycotoxins by seed- borne fungi of finger millet (Eleusine coracana L.). International Journal of Biotechnology and Molecular Biology Research, 1(5), 62- 64.

Pitt, J. I. (1979). The genus Penicillium and its teleomorphic states Eupenicillium and Talaromyces. Academic Press, London, 634 pp. http://dx.doi.org/10.1002/jobm.19810210822

Pitt, J. I., Hocking, A. D., Samson, R. A. \& King, A. D. (1992). Recommended methods for mycological examination of foods. In: Samson R. A., Hocking A. D., Pitt J. I. and King A. D. (editors), Modern Methods in Food Mycology. Elsevier, Amsterdam, 365-368pp.

Pitt. J. I. \& Hocking, A. D. (2009). Fungi and food spoilage. $3^{\text {rd }}$ edition, Springer Science and Business Media, 519 pp.

http://dx.doi.org/10.1007/978-0-387-92207-2

Raper, K. B. \& Fennell, D. I. (1965). The genus Aspergillus Williams and Wilkins, Baltimore, Maryland, 686 pp.

Reddy, N., Rao, K. \& Ahmed, I. (2004). Geographical patterns of diversity in pearl millet germplasm from Yemen. Genetic Resources and Crop Evolution, 51 513-517. http://dx.doi.org/10.1023/B:GRES.0000024151.00362

Samson, R. A. \& Varga, J. (2007). Aspergillus systematics in the genomic era. Studies in Mycology 59: pp. 207.

Singh, S., Bali, V., Sharma, L. \& Mangla, J.( 2014). Production of fungal amylases using cheap, readily available agriresidues, for potential application in textile industry. BioMed Research International, 9 pp. http://dx.doi.org/10.1155/2014/215748

Ulfig, J., Ulfig K. \& Markowska A. (2009). Extracellular enzyme profiles of xerophilic fungi isolated from dried materials of medicinal plants. Polish Journa of Environmental Studies, 18(3), 391-397.

Varga, J., Frisvad, J. C. \& Samson, R. A. (2007). Polyphasic taxonomy of Aspergillus section Candidi based on molecular, morphological and physiological data Studies in Mycology 59: 75-88.

Zohri, A. A., Saber, S. M., Youssef, M. S. \& Abdel-Kareem, M. M. (2014) Isolation and identification of toxigenic fungi from foodstuffs at Sohag Governorate, Egypt. Journal of Environmental Studie 